\title{
Pemberdayaan Pemuda Putus Sekolah Pulo Geulis Melalui Peningkatan Pengetahuan Pemasangan Instalasi Listrik
}

\author{
Anik Tjandra $\mathrm{S}^{1}$, Sri Danaryani ${ }^{2}$, Silo Wardono ${ }^{3}$, Isdawimah $^{4}$ \\ $1,2,3,4$ Jurusan Teknik Elektro, Politeknik Negeri Jakarta \\ A J1. Prof. Dr. G.A. Siwabessy Politeknik Negeri Jakarta, Kampus Baru UI Depok e-mail: \\ 1 anik.tjandrasetiati@elektro.pnj.ac.id, 4 isdawimah@elektro.pnj.ac.id
}

\begin{abstract}
Abstrak
Kampung Pulo Geulis memiliki topografi yang indah diapit dua aliran sungai dengan masyarakat beraneka ragam yang dihuni oleh etnis tionghoa dan sunda. Wilayah ini sangat padat penduduknya. Sebagian besar lahan sudah dibangun rumah dengan pemasangan instalasi listrik belum sesuai dengan ketentuan yang ada, hal ini disebabkan kurangnya pengetahuan masyarakat tentang listrik. Kondisi seperti ini dapat mengakibatkan bahaya baik terhadap keselamatan rumah, lingkungan dan terhadap keselamatan manusia itu sendiri. Pengabdian masyarakat ini bertujuan untuk memberikan pengetahuan tentang bahaya listrik, cara mencegahnya, dan memasang instalasi listrik yang sesuai dengan ketentuan yang berlaku pada Persyaratan Umum Instalasi Listrik (PUIL). Bentuk kegiatannya adalah penyuluhan, pelatihan dan praktek pemasangan instalasi listrik kepada pemuda putus sekolah. Materi yang diberikan antara lain: sambungan kabel, loop kabel dan pemasangan kabel, instalasi box sekering, saklar tunggal dan saklar seri serta merangkai lampu, instalasi saklar, dan instalasi saklar hotel dan stop kontak. Dengan adanya kegiatan ini, pemuda putus sekolah mampu memasang dan merawat instalasi listrik di rumah dan lingkungan agar berfungsi dengan baik dan aman. Selain itu keterampilan ini dapat dijadikan sebagai modal untuk membuka usaha di bidang instalasi listrik sehingga dapat menumbuhkan ekonomi mandiri bagi mereka. Meningkatnya perekonomian mereka maka lingkungan ini bisa tertata dengan baik sehingga dapat dikembangkan menjadi kampung wisata unggulan di kota Bogor.
\end{abstract}

Kata kunci: Listrik, instalasi listrik, pemuda putus sekolah, kampung wisata 


\section{PENDAHULUAN}

Kampung Pulo Geulis merupakan sebuah pulau kecil yang terletak di tengah Sungai Ciliwung di Kota Bogor, tepatnya di sebelah selatan Kebun Raya Bogor. Pulau ini berlokasi di sebuah desa yang terletak di Kelurahan Babakan Pasar, Kecamatan Bogor Tengah.

Pulo Geulis ini memiliki potensi untuk dikembangkan menjadi kampung wisata unggulan di kota Bogor sebab topografinya yang indah diapit dua aliran sungai Ciliwung dengan masyarakat beraneka ragam yang dihuni oleh etnis tionghoa dan sunda. Kampung ini juga memiliki akulturasi budaya yang sangat unik dimana terdapat Wihara yang dibangun pada abad ke-18, yang diyakini sebagai klenteng pertama di Bogor, yaitu Klenteng Phan Ko Bio. Tempat yang sangat kental dengan nilai- nilai pluralism dari suku, budaya, dan agama. Kehidupan dan kerukunana masyarakat Pulo Geulis diprediksi akan menjadi magnet baru bagi wisata kota Bogor.

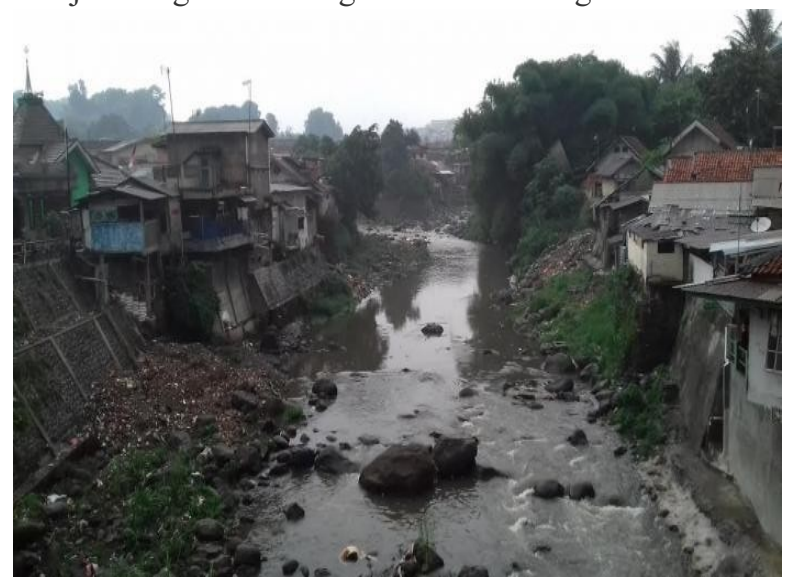

Gambar 1. Wilayah Kampung Pulo

Geulis

Luas wilayah Pulo Geulis sekitar 3,5 hektare, dihuni oleh 770 kepala keluarga dengan jumlah penduduk kurang lebih 2.640 jiwa; bisa dikatakan sangat padat penduduknya, sebagian besar lahan sudah dibangun rumah dan banyak rumah yang instalasi listriknya belum sesuai dengan ketentuan yang ada, hal ini disebabkan kurangnya pengetahuan masyarakat tentang listrik. Kondisi seperti ini tentunya dapat mengakibatkan bahaya baik terhadap keselamatan rumah, lingkungan dan terhadap keselamatan manusia itu sendiri. Listrik merupakan kebutuhan yang sangat vital dan merupakan komponen yang sangat utama bagi kehidupan di Pulo Geulis khususnya dalam rumah.

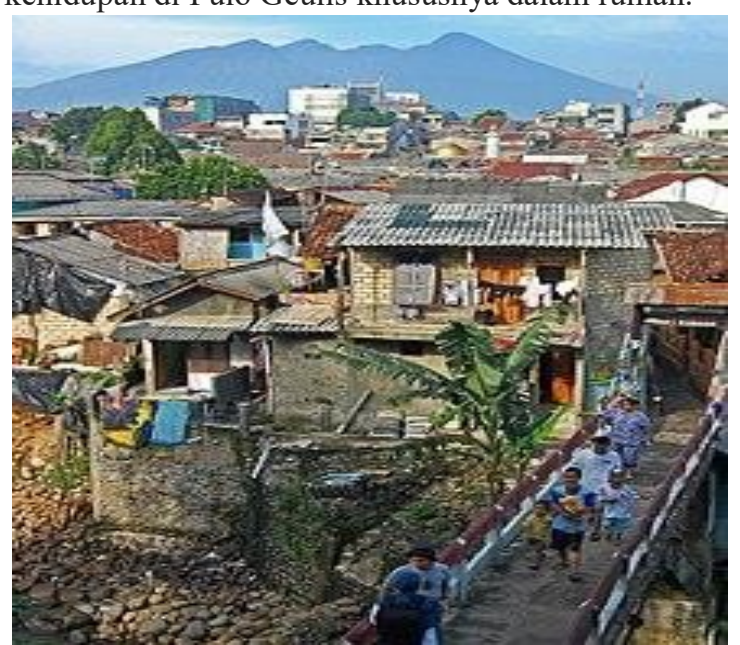

Gambar 2. Rumah masyarakat di kampong Pulo Geulis

Mayoritas penduduk Pulo Geulis berdagang dengan penghasilan yang tidak menentu, ada usaha pembuatan tas dan usaha baju penari barongsay. Di daerah ini juga banyak pemuda putus sekolah yang belum bekerja.

Berdasarkan survey di lapangan , masyarakat pulo Geulis masih banyak yang belum tahu bagaimana mengoptimalkan penggunaan tenaga listrik yang ada. Mereka belum tahu tentang bahaya dan cara mengatasi jika terjadi gangguan listrik. Masyarakat belum tahu cara memasang instalasi listrik yang sesuai dengan ketentuan.

Dengan analisa di atas maka perlu diberikan pengertian, pengetahuan tentang listrik dan instalasi listrik baik secara teori 
maupun praktek agar masyarakat Pulo Geulis dapat mengoptimalkan tenaga listrik yang ada untuk kepentingan usaha dan rumah tangga, bisa menghindari bahaya listrik serta bisa melakukan instalasi listrik sendiri. Keterampilan instalasi listrik ini dapat digunakan oleh masyarakat khususnya pemuda putus sekolah sebagai mata pencarian untuk meningkatkan perekonomian mereka. Diharapkan dengan meningkatnya perekonomian mereka maka lingkungan ini bisa tertata dengan baik sehingga dapat dikembangkan menjadi kampung wisata unggulan di Kota Bogor.

Program pengabdian ini bertujuan untuk memberdayakan pemuda putus sekolah melalui peningkatan pengetahuan pemasangan instalasi listrik dengan cara memberikan pengertian, pengetahuan tentang listrik, memperbaiki dan memasang instalasi listrik yang benar secara teori maupun praktek kepada masyarakat khususnya pemuda putus sekolah di Kampung Pulo Geulis. Selain itu bertujuan agar mereka memiliki pengetahuan tentang keselamatan dalam menggunakan listrik, bahaya listrik dan bisa mengatasi jika terjadi gangguan listrik.

\section{METODE PENGABDIAN}

Kegiatan pengabdian masyarakat dilakukan melalui tahapan persiapan, pelaksanaan dan evaluasi. Yang terlibat dalam kegiatan ini antara lain dosen, teknisi dan mahasiswa Jurusan Teknik Elektro PNJ sebagai penyelengara pengabdian dan Lurah, RW IV, 5 (lima) RT, pemuda putus sekolah Kampung Pulo Geulis Kelurahan Babakan Pasar, Kecamatan Bogor Tengah sebagai mitra.

Pada tahap persiapan kegiatan yang dilakukan adalah survey kondisi lokasi pengabdian; wawancara dan diskusi dengan lurah, RW, RT dan masyarakat tentang permasalahan utama yang dihadapi, diskusi tentang metode dan penyelesaian permasalahan yang dihadapi serta menawarkan solusi yang ditawarkan oleh penyelengara pengabdian.

Tahap pelaksanaan pengabdian dimulai dengan koordinasi tentang pembagian tugas kegiatan. Pihak penyelenggara membuat modul pelatihan, persiapan bahan, peralatan dan konsumsi selama pelatihan sedangkan pihak mitra menentukan nama peserta pelatihan, waktu dan tempat pelatihan. Pelatihan instalasi listrik diberikan secara teori maupun praktek oleh dosen, teknisi dan mahasiswa. Pelatihan teori instalasi listrik dilakukan di kantor kelurahan sedangkan praktek pemasangan instalasi listrik dilakukan dengan memperbaiki instalasi kantor RW IV.

Tahap terakhir dari kegiatan ini adalah evaluasi hasil pelaksanaan dan kendala-kendala yang dihadapi selama kegiatan, monitoring kemampuan peserta pasca kegiatan dengan melibatkan peserta untuk memperbaiki dan merawat instalasi penerangan yang telah dibuat.

\section{HASIL PEMBAHASAN}

Hasil kegiatan pengabdian pada masyarakat secara garis besar mencakup beberapa komponen sebagai berikut: keberhasilan target jumlah peserta pelatihan, ketercapaian tujuan pelatihan, dan ketercapaian target praktek langsung dengan melakukan perbaikan instalasi listrik di kantor RW.

Target peserta pelatihan seperti direncanakan sebelumnya adalah 15 orang. Dalam pelaksanannya, kegiatan ini diikuti oleh 13 orang peserta. Dengan demikian dapat dikatakan bahwa target peserta tercapai $92 \%$. Angka tersebut menunjukkan bahwa kegiatan pengabdian masyarakat dilihat dari jumlah peserta yang mengikuti dapat dikatakan berhasil/sukses. 
Ketercapaian materi pelatihan secara umum baik, peserta sangat antusias dan semangat mengikuti pelatihan dari awal sampai akhir kegiatan. Mereka sangat tertarik dengan materi pelatihan yang menambah pengetahuan tentang pemasangan instalasi listrik yang baik dan benar. Hal ini dapat dilihat dari beberapa pertanyaan yang diajukan oleh peserta dan keterlibatan mereka dalam memperbaiki kantor RW sampai pukul 18.00. Dari pelaksanaan pengabdian ini maka dapat disimpulkan bahwa tujuan kegiatan tercapai.

\section{KESIMPULAN}

Berdasarkan jumlah peserta yang ikut pelatihan yaitu $92 \%$ dari target, ketercapaian materi pelatihan dan keterlibatan mereka dalam praktek memperbaiki instalasi kantor RW serta hasil evaluasi monitoring setelah kegiatan dilakukan maka dapat disimpulkan bahwa kegiatan pengabdian ini berhasil dan tercapai sesuai dengan tujuan.

\section{DAFTAR PUSTAKA}

Badan Standarisasi Nasional (BSN).

2000. Persyaratan Umum Instalasi Listrik

2000 (PUIL 2000). Adopsi Standar Nasional Indonesia (SNI). Yayasan PUIL. Jakarta

http://bogor.tribunnews.com/2019/02/28/ tribun-wikiasal-usul-nama-kampung- pulo-geulis-bogortiapjelang-senja-ada- sosok-cantik-berkebaya

$\begin{array}{lrrr}\text { National } & \text { Safety } & \text { Council } \\ \text { (http://www.nsc.centralohio.org/ } & \text { diakses } & \text { tanggal } \\ \text { 10April 2012) } & & \end{array}$

